\title{
The Influence of Cultural Differences on English and American Literature Review
}

\author{
Sa Xie \\ Hainan Institute of Science and Technology, Haikou Hainan, 570208, China
}

Keywords: Cultural differences, English and American literary criticism, Influence.

\begin{abstract}
The national culture is influenced by the environment, history and other factors, it is more than embodiment but also soul and spirit of a nation. Cultural differences between ethnic groups formed the diversity of world culture, rich patterns, make the world culture show a colorful gesture. This paper expounded features and reviews characteristics of British and American literature,then conducted a analyses on the influence of the production of Anglo American literary criticism from the perspective of cultural differences, and put forward under the influence of cultural differences in the humanitarian ideas.
\end{abstract}

\section{Introduction}

Literary works is not only a kind of ideological expression of the author, but also a reflection of the national culture of the time. In British and American literary works, the main forms of the existence of novels, poetry, drama, prose, etc. All of these works have condensed cristalization of the author's creation emotion and wisdom, and also bear the important task of national culture's display and inheritance. There are a lot of similarities and connections between British and American cultures, but due to the national political, economic, cultural, customs and geographical factors, there are essential differences between the two cultures. This difference of culture has a different impact on literary works, of course, also affect the literature review..

\section{The characters between Amrican and British literature review}

Through the list of world top class literatures and the authors, both Britain and the United States was creddles for many outstanding literary masters and famous literary works. English is the carrier of the English and American literature, the writer complete the work by art and fiction techquites,reflecting the life related things or situations, and offfering its unique aesthetic. As the acrrier English lanauge can emphasis unique charm and chararcters of British and American literature, the English have unique advantages,it is rich in vocabulary and distinctive reading rhythm sense; the pronunciation intonation and with the music melody similarity, which infecte the shading of English and American literature into a layer of artistic atmosphere. Although the British and American culture is expressed through English, but its style and show a different look.

\section{Character of British literature.}

British literature has a long history of development, in the long river of literature, there have been a lot of dazzling bright pearl. Characteristics of English literature mainly in the narrative of the Empire, which has a long history and culture, and have appeared in the heyday of the British Empire, under this kind of historical atmosphere, the literary works also revealed great confidence [1]. In British literary works keept detailed records recorded the from the started of the British Empire, the prosperity and decline; for example, British famous war literature, literary explorations and literary system both show their pride of countries such as Britain and there is apparent expansion of consciousness. In addition, more common literature and utopian literature, the literature system for british is political literature in all kinds, based on the confidence of the British Empire, depicts a with British characteristics of ideal kingdom, which is full of literary home of British development ideas and wishes. The famous works of utopian literature are directly named after the utopia, which is the work of Thomas Moore, a famous British writer. 


\section{Analysis to the characteristics of American Literature.}

The development of American literature has a great influence by English literature, but it also has its own characteristics due to the influence of economic and political foundation. The morphological structure of American literature has diversity, according toits development context , it can be divided into: realistic literature, local literature and romantic literature. Which American romantic literature in the world literature with distinct characteristics, but also with the British literature is the most prominent differences in the performance of [2]. Romantic literature pay more attention to emotional freedom of expression, show more sprightly rhythm on the writing techniques, the depiction of the protagonist also more abound personalized, the thicks of British literature exist obvious differences.

\section{The influence of british cultural to American}

Based on comparament between literatures between American and British we can realize that there are both similirities and differents between the British and American. but we must recognize some differences is caused by the impact of British literary criticism. The form of social existence determines the existence of social consciousness, and the social consciousness is a reflection of the reality of the social form. This caused although there is some connection the British and American literature, since the difference of social existence made during the history of national development. It also determines the differences between British and American literature and literary criticism is bound to have significantly different. Literary criticism is influenced by many factors, such as the personal style, interest and emphasis of the critics, and the most important factor is the cultural difference among all the factors.

The influence of linguistic differences between English and American literature review.

As the main carrier of culture, language has great influence on English and American literature review. In the literary works in language needs after the continuous processing and refining to highlight the literary works of art, and language expression, application and artistic processing way and with their own culture has great relevance, so the language difference is the main manifestation of the cultural differences between the two countries.

Language for both of British and American is English, but the history and the development of English also has thousands of years; with the history of development and the Britsh influenced in the international status, English has become the language of world diplomacy, the development of all aspects of the world have important significance.

British English has a very authentic, and it contains a sense of British culture and history with thickness. The expression form of the language is shown in the comments in English literature feature is too observant of conventional standards. there are two reasons, one is conservative,:another is the British character, the British character is more conservative, unassuming, in literary criticism theory is revealed objectively not conservative, gave away the reservations in the comments; second, although more in English speaking countries, but it is really the origin of British English, so the English have an other people without fear and sense of the sacred in English, which leads to the literary writer and literary critic would have scruples in the process the use of English, in the use of language will be more cherish ${ }^{[3]}$ 。

The United States used to be a British colony, although has been following the British in language, but because of the development process and the history of the two countries to form different forms of use of different languages. America is a nation separated from a British colony.The process of the development of the society is directly from the slave society into capitalist society, the social form the is lack of process of feudal society, the American did not bear a heavy history , this in the literary criticism reflect that the use of English language too bold, insolent and rich innovative spirit, which is the United States to get rid of British rule a catharsis. Lacking of and cultural background of the United States in the literary criticism is also a highlighted personalized, which makes a review of the literature language rebellious, insolent, bold and outspoken and full of vitality.

The influence of cultural differences on English and American literary criticism.

In addition to the influence of linguistic differences on English and American literary criticism, 
the differences of cultural connotation between the two countries are the main factors that influence the literature review.

Through the analysis of the review of the English literature, it can be found that the content has been hovering between the rebellion and inheritance. This point in the famous British writer Shakespeare's work, "Hamlett" in the statement reflected in the. "Survive or perish, is a problem," this sentence as a literary classic famous bring millions of people thinking, but also for the British conservative and indecisive character of a true portrayal. Similar to the history of British literature reviews the development course and the UK, by original religious comments technique gradually to the absurd way, marginal experience concept innovation mode of transition, reflecting the development of British literary critics, the British critics continue to break the old thinking, rebuild new comment system performance incisively and vividly [4]. But through the study of English review of the history of the development can be found, from the 70s of the 20th century began to British literary theory has been stagnant, there is no innovation theory studies and literary theory everybody, but constantly in the inheritance and breakthrough wandering. Although the British literary theory research has been stagnant, but it can not be denied that the British literary theory of rigor, the history of the thick and the traditional theory of the United States can not be compared to the theory of literature. From the master of English literature can be seen, in the tradition of British literary theory under the guidance of British Shakespeare, Dickens, Goethe and other famous literary people and their famous literary classics.

And American literary criticism is almost at the same time with the development of American literature. American from the British independent from Britsh, so there is no bear too much historical baggage, there is no after a long feudal society history, so the country's political, economic and cultural are new, the United States open society laid a certain foundation. Its literary criticism can absorb the outstanding literary heritage of all countries in the world. In the process of absorbing the culture of other countries, it also broadens the horizon of American literary criticism. Due to the absence of the inheritance of local culture, so they constantly to his country's excellent culture absorbed, by contrast, learn from each other, so I used, continuous innovation and change, to an absolute open philosophy absorb all kinds of literary system, and gradually reconfiguration belongs to his country's literature system. This is burdened with the heavy historical imprint in the UK.

\section{Analysis of the influence of cultural differences from the perspective of Humanism}

Humanism is one of the typical charactor of America in literature. The humanism of English and American literature formulated on their own way, which is related to its own historical origin, but in general it can be summarized has close connection with the humanism, relative asceticism and theocratic. Influenced by different historical forms, the United Kingdom put forward more conservative and more conservative, but the American literature is more radical and creative.

Shakespeare, a master of English literature, is one of the most famous writers in English literature. He made great influence $n$ to English literature. Shakespeare advocated humanism, this kind of thought influence the British of social revolutions have held suspicion and negation, Shakespeare not only to Britain has profound effect but also has the profound influence on other countries in Europe. For example, Gerd, Dickens and so on, they are opposed to violent revolution tend to be modified. Against violence, to promote peace, to advocate forgiveness, to carry forward the universal love is the main form of humanism.

For the English literary critics and other English cultural influence of the European literature, the final aim is to achieve world peace, the elimination of class constraints and constraints. And many people are skeptical of this humanitarian, the main reason is because the revolution is the main means to promote social change and progress. And revolutionary means never isn't a gentle, need resort to violence to compete for dominance, because there is no any a were revolutionaries will take the initiative to surrender regime [5]. At the same time, the transformation of the human mind can not be done overnight, must go through the process from the outside to the inside. Need to clear people's thinking by the impact of social environment, if you ignore the people's autonomy and independence, 
it will be mistaken for the revolution can make people's ideological problems to be thoroughly resolved. Many people do not believe in moral binding, and the degree of moral constraints can not be quantified and formulated standards, so people will inevitably have doubts about the behavior of others.

Relative review of American literature, because it belongs to the emerging countries, did not experience the baptism of history, the inheritance of local culture does not exist naturally, so an American literary critic in the development process of no historical burden of negative tired to traveling light, avoid facing the revolution and moral judgment. Led to the United States in the process of humanitarian proposed bold, radical and creative.

\section{Conclusion}

In summary, cultural differences have a profound impact on British and American literary criticism. Britain's literary criticism is too conservative, has been wandering in the inheritance and innovation, and critics in the American literary bolder, straightforward and creative. On the one hand, due to the impact of the language, while the common language is English, but because the origin of English in the UK so British literary criticism will be of language, the use of the existence of a sense of awe, leading to overly cautious comments. While the United States because as a British colony and English is spoken as a native language, so in the process of application of the few scruples. In literary criticism words more bold, sharp, straightforward. And the cultural connotation of the two countries are also different Britain saddled with thousands of years of historical burden, in the literary criticism should not only inherit but also need innovation, while the United States belongs to new countries can be traveling light, which is open in American society. So American Literary Review on innovation is Britain to match, and the British tradition of is the United States not be comparable to the.

\section{References}

[1] Zhang Wei. Research on influence of Anglo American cultural differences on American literature review, Xijiangyue, 2014 (12): 444-444.

[2] Qiu Xiaorong, Zhang Meifeng, Li Na et al. Discussion on the influence of cultural differences on English and American literature review, College entrance examination, 2015 (4): 126-126.

[3] Zhang Yao. Influence of British and American cultural differences on English and American literature review, Journal of Heilongjiang Institute of education, 2015 (8): 99-100.

[4] Zhang Yao. Influence of Anglo American cultural differences on English and American literature review, Journal of Kaifeng Institute of Education, 2015 (8): 42-43.

[5] Zhang Huining. Discussion on the influence of cultural differences on English and American literature review, Overseas English (On), 2015 (1): 8-9,14. 